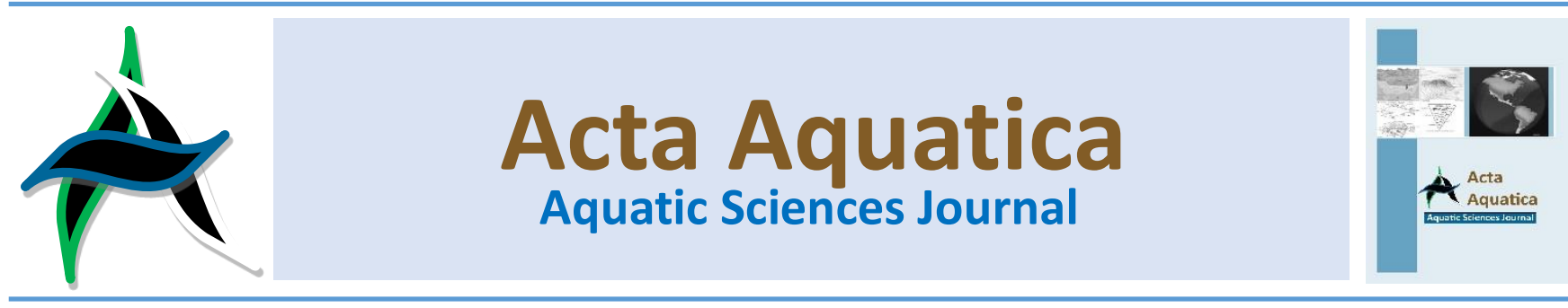

\title{
Potensi rumput laut: Kajian komponen bioaktif dan pemanfaatannya sebagai pangan fungsional
}

\section{Seaweed potential: bioactive compounds studies and its utilization as a functional food product}

\author{
Erniati $^{a, b} *$, Fransiska Rungkat Zakaria ${ }^{b}$, Endang Prangdimurti ${ }^{b}$ dan Dede Robiatul Adawiyah ${ }^{b}$ \\ a Program Studi Budidaya Perairan, Fakultas Pertanian, Universitas Malikussaleh \\ ${ }^{b}$ Departemen Ilmu dan Teknologi Pangan, Fakultas Teknologi Pertanian, Institut Pertanian Bogor
}

\begin{abstract}
Abstrak
Rumput laut merupakan sumber daya hayati yang sangat berlimpah di perairan Indonesia. Namun demikian pemanfaatannya untuk pengolahan produk pangan sangat terbatas, terutama untuk produk pangan fungsional. Rumput laut berpotensi dikembangkan sebagai produk pangan fungsional karena mengandung zat gizi dan komponen bioaktif yang berkhasiat untuk kesehatan. Rumput laut mengandung sejumlah komponen bioaktif seperti senyawa fenolik, pigmen alami, polisakarida sulfat, serat dan komponen bioaktif lainnya yang telah diteliti berkhasiat untuk kesehatan. Untuk dapat dikembangkan sebagai produk pangan fungsional, rumput laut yang digunakan harus bebas dari cemaran logam berat dan bahan pencemar lainnya, harus mengandung komponen bioaktif dan zat gizi yang tinggi sehingga harus ada penerapan standar penanaman dan penanganan pasca panen yang baik di tingkat petani rumput laut. Selain itu Proses pengolahan pangan yang diterapkan tidak merusak komponen bioaktif yang terkandung dalam rumput laut. Optimalisasi pengolahan rumput laut sebagai produk pangan fungsional merupakan alternative pemanfaatan potensi rumput laut Indonesia yang dapat meningkatkan nilai ekonomi rumput laut dan yang lebih penting dapat menyediaakan akses pangan sehat bagi masyarakat luas.
\end{abstract}

\begin{abstract}
Seaweed is a living resource that is abundantly available in Indonesian water. However, its utilization in food processing is very limited, especially as functional food products. Seaweed has the potential to be developed as functional food products because it has nutrient and bioactive components that are beneficial for health. Seaweed has a number of bioactive components such as phenolic compound, natural pigment, polysaccharide sulphate, fiber and other bioactive components that has been studied to be advantageous for health. For a seaweed to be developed into functional food product, it must be free from heavy metal and other pollutant contamination, and must contain bioactive components and high nutrients, thus, a good cultivation and postharvest handling standard have to be applied in seaweed farmer level. Moreover, the food processing applied should not damage the bioactive component within the seaweed. Optimization of seaweed processing into functional food product is an alternative for seaweed potential utilization in Indonesia, which could improve the economic value of the seaweed, and more importantly it could provide access for healthy food for community.
\end{abstract}

Keywords: Seaweed; bioactive components; functional food

\footnotetext{
* Korespondensi: Prodi Budidaya Perairan, Fakultas Pertanian, Universitas Malikussaleh. Kampus utama Reuleut,

Kabupaten Aceh Utara, Aceh, Indonesia.

Tel: +62-645-41373 Fax: +62-645-59089.

e-mail:erniatiunimal@gmail.com
}

\section{Pendahuluan}

Rumput laut atau lebih dikenal dengan sebutan seaweed merupakan sumber daya hayati yang sangat melimpah di perairan Indonesia. Keanekaragaman rumput laut di Indonesia merupakan yang terbesar dibandingkan dengan negara lain. Berdasarkan data Kementrian Kelautan dan Perikanan (2014), total produksi rumput laut Indonesia mencapai 5,6 juta ton pada tahun 2013. Hasil ini menjadikan Indonesia sebagai negara produsen rumput laut terbesar kedua di dunia setelah Cina. Namun demikian sampai saat ini pemanfaatan rumput laut Indonesia belum dilakukan secara optimal, khususnya 
pemanfaatan sebagai bahan baku untuk produk pangan fungsional yang dapat memberikan manfaat kesehatan bagi masyarakat. Pemanfaatan rumput laut sebagai bahan baku untuk pangan fungsional di Indonesia masih belum banyak dibahas. Sumber daya rumput laut yang besar di Indonesia sampai saat ini sekitar $75 \%$ di ekspor keluar negeri dalam bentuk bahan baku mentah rumput laut kering, hanya sekitar $25 \%$ yang dilakukan pengolahan atau sebagai bahan baku industri dalama negeri.

Pangan fungsional merupakan pangan dalam bentuk produk pangan normal yang dikonsumsi sebagai makanan dan minuman yang dapat memberikan efek manfaat bagi kesehatan selain manfaat zat gizi yang dikandungnya (Zakaria, 2015). Menurut definisi ini suplemen atau obat tidak dapat dikategorikan pangan fungsional.

Rumput laut telah dimanfaatkan oleh masyarakat dunia sebagai bahan makanan, obat-obatan dan bahan baku kosmetik. Di Indonesia juga masyarakat pesisir sudah sejak lama memanfaatkan rumput laut sebagai bahan pangan dan juga untuk pengobatan (Anggadiredja et al., 2006). Pemanfaatan rumput laut yang luas di bidang pangan, neutraceutical, suplemen dan juga kosmetik disebabkan oleh komposisi nilai gizi dan komponen bioaktif yang terdapat pada rumput laut tersebut. Sumber daya rumput laut yang besar di Indonesia jika dilakukan pengolahan yang tepat akan dapat menghasilkan produk pangan fungsional bagi masyarakat luas. Untuk dapat dikategorikan sebagai produk pangan fungsional, maka produk pangan olahan rumput laut harus mengandung zat gizi, serat dan komponen bioaktif yang tinggi yang hampir sama dengan kandungan pada bahan bakunya.

Berdasarkan latar belakang tersebut maka dalam tulisan ini ingin dibahas lebih jauh kandungan komponen bioaktif rumput laut dan potensi pemanfaatan rumput laut sebagai produk pangan fungsional, Diharapkan tulisan ini dapat memberikan manfaat dalam peningkatan nilai tambah rumput laut Indonesia khususnya untuk menghasilkan produk pangan yang memberikan efek positif untuk kesehatan.

\section{Komposisi kimia rumput laut}

Rumput laut mempunyai komposisi kimia yang berbedabeda (Tabel 1). Perbedaan komposisi kimia rumput laut dipengaruhi oleh beberapa faktor. Beberapa faktor tersebut adalah perbedaan genetik, spesies, habitat tumbuh, umur panen dan juga kondisi lingkungan (Ortiz et al., 2006; Sanchez-Machado et al, 2004).

Di Indonesia komposisi nilai gizi rumput laut sudah banyak dilaporkan. Loupatty (2014) melaporkan rumput laut Porphyra marcossi dari Maluku mempunyai nilai gizi yang cukup tinggi yaitu: protein $28,60 \%$; lemak $0,83 \%$; abu $17,80 \%$ dan air $28,09 \%$. Yunizal (2004) menyatakan rumput laut Sargassum dari Kepulauan Seribu mengandung karbohidrat 19,06\%, protein $5,53 \%$, lemak $0,74 \%$, air $11,71 \%$, abu $34,57 \%$ dan serat kasar $28,39 \%$.

Rumput laut juga mengandung sejumlah mineral tertentu seperti $\mathrm{P}, \mathrm{Na}, \mathrm{K}, \mathrm{Ca}, \mathrm{Mg}, \mathrm{Fe}, \mathrm{Cu}, \mathrm{Zn}$ dan $\mathrm{Mn}$. AstorgaEspana et al. (2015) menyebutkan bahwa jenis rumput laut merah, hijau dan rumput laut coklat mengandung mineral yang bervariasi. Rumput laut coklat mengandung mineral $\mathrm{K}$ dan $\mathrm{Ca}$ yang lebih tinggi $(\mathrm{K}=31,4 \mathrm{~g} / \mathrm{kg}, \mathrm{Ca}=10,3 \mathrm{~g} / \mathrm{kg})$ dibandingkan rumput laut merah $(\mathrm{K}=14.1 \mathrm{~g} / \mathrm{kg}$ dan $\mathrm{Ca}=3.11 \mathrm{~g} / \mathrm{kg})$ dan rumput laut hijau ( $\mathrm{K}=13.9 \mathrm{~g} / \mathrm{kg}$ dan $\mathrm{Ca}=7.58 \mathrm{~g} / \mathrm{kg}$ ). Rumput laut hijau mengandung mineral $\mathrm{Mg}(15.0 \mathrm{~g} / \mathrm{kg})$, Fe $(1260 \mathrm{mg} / \mathrm{kg})$ dan $\mathrm{Cu}$ $(7.46 \mathrm{mg} / \mathrm{kg}$ ) yang lebih tinggi dibandingkan rumput laut coklat dan rumput laut merah. Berdasarkan kandungan mineral, dikatakan bahwa konsumsi 8 gram rumput laut (berat kering) akan dapat memenuhi lebih dari $25 \%$ kebutuhan harian mineral $\mathrm{Mg}$, Fe dan Cu tubuh manusia.

Tabel 1

Komposisi kimia beberapa jenis rumput laut.

\begin{tabular}{|c|c|c|c|c|}
\hline \multirow{2}{*}{ Jenis rumput laut } & \multicolumn{4}{|c|}{ Komposisi kimia (g / $100 \mathrm{~g}$ berat kering) } \\
\hline & Karbohidrat & Protein & Lipida & Mineral \\
\hline \multicolumn{5}{|l|}{$\begin{array}{l}\text { Chlorophyceae } \\
\text { (rumput laut hijau) }\end{array}$} \\
\hline Ulva spp & 42,1 & $20-26,1$ & $0,6-0,7$ & $13,7-22,6$ \\
\hline Ulva lactuta & NA & $10-21$ & NA & NA \\
\hline $\begin{array}{l}\text { Enteromorpha } \\
\text { spp }\end{array}$ & 61,5 & 20,7 & 0,3 & 6,6 \\
\hline \multicolumn{5}{|l|}{$\begin{array}{l}\text { Phaeophyceae } \\
\text { (rumput laut coklat) }\end{array}$} \\
\hline Laminaria spp & 49,1 & 6,7 & 1,6 & 19,2 \\
\hline Konbu & NA & $8,1-15$ & 1,8 & 25,4 \\
\hline $\begin{array}{l}\text { Undaria } \\
\text { pinnatifida }\end{array}$ & 47,8 & $\begin{array}{l}12,7- \\
14,1\end{array}$ & $1,5-2,7$ & $21,2-32,8$ \\
\hline $\begin{array}{l}\text { Hizikia } \\
\text { fusiforme }\end{array}$ & 29,8 & $5,6-12,3$ & $0,8-1,5$ & $21,2-35$ \\
\hline Fucus & NA & $3-11$ & NA & NA \\
\hline \multicolumn{5}{|l|}{$\begin{array}{l}\text { Rhodophyceae } \\
\text { (rumput laut merah) }\end{array}$} \\
\hline $\begin{array}{l}\text { Porphyra } \\
\text { tenera }\end{array}$ & 40,5 & $33-47$ & $0,7-1,6$ & $8,5-8,7$ \\
\hline $\begin{array}{l}\text { Chondrus } \\
\text { crispu }\end{array}$ & 54,8 & 11,2 & 2,6 & 14,2 \\
\hline Gracilaria & 58,4 & 7,9 & 0,1 & 17,8 \\
\hline
\end{tabular}

\section{Kandungan komponen bioaktif rumput laut}

Ditinjau dari kandungan komponen bioaktif, rumput sangat berpotnsi dikembangkan sebagai produk pangan fungsional. Komponen bioaktif pada rumput laut sangat bervariasi tergantung dari beberapa faktor diantaranya spesies, kondisi geografis, musim, lingkungan, musim panen, suhu air, penanganan pasca panen (Mabeau et al. 1993; Nisizawa et al. 1987; Yoshie et al. 1994). Komponen bioaktif pada rumput laut sangat luas seperti senyawa fenolik, pigmen alami, polisakarida sulfat, serat ataupun senyawa halogen (Pangestuti dan Kim, 2011; Farvin dan Jacobsen, 2013 ; Holdt dan Kraan, 2011).

\subsection{Komponen fenolik rumput laut}

Senyawa fenolik termasuk salah satu senyawa penting yang tergolong ke dalam senyawa antioksidan alami (Machu et al. 2015). Senyawa fenolik terdiri atas molekul-molekul besar dengan beragam struktur, karakteristik utamanya adalah adanya cincin aromatik yang memiliki gugus hidroksil. Kebanyakan senyawa fenolik termasuk ke dalam kelompok flavonoid (Pratt dan Hudson, 1990).

Senyawa fenolik termasuk salah satu komponen bioaktif yang terdapat secara luas pada rumput laut. Berbagai jenis senyawa fenolik dengan kadar yang berbeda-beda telah diekstraksi pada rumput laut dan diuji khasiatnya untuk kesehatan, diantaranya asam fenolat, catechin, phlorotannins, flavonoid termasuk flavon dan flavonol glycosides telah teridentifikasi dalam rumput laut coklat, rumput laut hijau dan rumput laut merah (Keyrouz et al., 2011; Farvin dan Jacobsen, 2013).

Phlorotanin merupakan senyawa polefenol berupa turunan tanin yang hanya terdapat pada rumput laut coklat dan konsentrasinya mencapai $25 \%$ dari berat kering. Senyawa ini terbentuk dari polimerisasi phloroglusinol melalui lintasan asetat-malonat. Terdapat bermacam jenis phlorotanin, diantaranya fuhalol, phloretol, hidroksiphlorethol, eckol, bieckol dan lain-lain (Firdaus, 2011). Selain phlorotanin, komponen bioaktif fenolik lain dari rumput laut juga menunjukkan 
bioactivity. S. myriocystum dan T. ornata dari pantai selatan Tamil Nadu, India mengandung senyawa asam fenolat dan flavonoid yang mempunyai aktivitas antioksidan (Jeyabalan dan Marimuthu, 2012).

\subsection{Natural pigmen (pigmen alami)}

Pigmen alami yang terdapat rumput laut dapat diklasifikasikan menjadi tiga kelas utama yaitu rumput laut coklat (Phaeophyceae), merah (Rhodophyceae) dan hijau (Chlorophyceae). Jenis pigmen alami yang utama terdapat pada rumput laut dibagi menjadi tiga kelas senyawa yaitu klorofil, karotenoids dan phycobiliproteins (Pangestuti dan Kim, 2011). Secara lebih rinci, pigmen alami yang terdapat pada ketiga kelas rumput laut disajikan pada Tabel 2 .

Tabel 2

Jenis pigmen alami rumput laut.

\begin{tabular}{|c|c|c|}
\hline Golongan rumput laut & Jenis rumput laut & Pigmen alami \\
\hline $\begin{array}{l}\text { Chlorophyta (rumput } \\
\text { laut hijau ) }\end{array}$ & $\begin{array}{l}\text { Enteromorpha } \\
\text { compresa }\end{array}$ & $\begin{array}{l}\text { Chlorophylls a, } \\
\text { Chlorophylls b, } \beta \text { - } \\
\text { carotens, lutein, } \\
\text { xanthophylls }\end{array}$ \\
\hline $\begin{array}{l}\text { Phaeophyta (rumput } \\
\text { laut coklat) }\end{array}$ & $\begin{array}{l}\text { Laminaria } \mathrm{sp}, H \text {. } \\
\text { fusiform, } U . \\
\text { pinnatifida }\end{array}$ & $\begin{array}{c}\text { Chlorophylls a, } \\
\text { Chlorophylls c, } \beta \text { - } \\
\text { carotens, fucoxantin, } \\
\text { xanthophyll }\end{array}$ \\
\hline $\begin{array}{l}\text { Rhodophyta (rumput } \\
\text { laut merah) }\end{array}$ & P. tenera & $\begin{array}{c}\text { Chlorophylls a, } \\
\text { Chlorophylls d, } \\
\text { phycocyanins, } \\
\text { phycoerythrin, } \alpha \text { - dan } 8 \text { - } \\
\text { carotenes dan } \\
\text { xanthophyl }\end{array}$ \\
\hline
\end{tabular}

Sumber : Bocanegra et al. (2009).

Klorofil dari rumput laut ini telah diteliti mempunyai aktivitas biologi yang sangat luas. Beberapa aktivitas biologis dari klorofil dari rumput laut disajikan pada Tabel 3.

Tabel 3

Jenis pigmen alami rumput laut.

\begin{tabular}{ccc}
\hline Jenis Klorofi & Aktivitas Biologis & Sumber \\
\hline Chlorofil a & Antioksidan & Enteromorpha prolifera \\
& Antimutagenic & Fucus vesiculosus \\
& Porphyra tenera \\
Pheophytin a & Neuroprotective & Sargassum fulvellum \\
& Antimutagenic & Enteromorpha polifera \\
& Anti-inflammatory & Enteromorpha polifera \\
Pheophorbide a & Antioksidan & Enteromorpha polifera \\
Pyropheophytin a & Antioksidan & Eisenia bicyclis \\
Phycoerythrobilin & Antioksidan & Porphyra sp. \\
\hline
\end{tabular}

Karotenoid merupakan pigmen alami yang terdapat pada semua spesies rumput laut. Karotenoid merupakan senyawa tetraterpenes, carotenes (hydrocarbons) dan xanthophylls yang mengandung molekul oksigen. Jenis rumput laut hijau mengandung karotenoid jenis $\beta$-carotene, lutein, violaxanthin, neoxanthin dan zeaxanthin. Pada jenis rumput laut merah mengandung karotenoid jenis $\alpha$ - dan $\beta$-carotene, lutein dan zeaxanthin. Sedangkan pada rumput laut coklat hanya terdapat karotenoid $\beta$-carotene, violaxanthin dan fucoxanthin (Holdt dan Kraan, 2011).

Sama halnya dengan klorofil, karotenoid yang terkandung pada rumput laut juga telah diteliti mempunyai aktivitas biologis untuk memperbaiki dan meningkatkan kesehatan. Lutein, $\beta$-karoten yang diekstrak dari Porphyra tenera telah diteliti mempunyai aktivitas antimutagenic pada bakteri Salmonella typhimurium (Okai et al., 1996).
Sementara itu fucoxanthin merupakan pigmen karotenoid yang telah diteliti mempunyai aktivitas biologis yang lebih luas dibandingkan karotenoid lain pada rumput laut coklat (Kim dan Pangestuti, 2011). Aktivitas biologis fucoxanthin yang terdapat pada jenis rumput laut coklat dapat berfungsi sebagai antioksidan, anti kanker, anti-inflamasi, anti obesitas dan lainlain (Kim dan Pangestuti (2011).

Phycobiliproteins adalah pewarna alami yang merupakan protein fluoresent yang larut air. Phycobiliproteins adalah photoreceptor utama pada proses fotosintesis rumput laut merah. Warna dari phycobiliproteins timbul karena adanya ikatan kovalen gugus prostetic, bilins yang linear dengan tetrapirol turunan biosintesis heme melalui biliverdin. Ada tiga jenis phycobiliproteins, yaitu phycocyanins, allophycocyanins dan phycoerythtins. Phycoerythtins merupakan phycobiliproteins yang terdapat secara umum pada rumput laut merah (Pangestuti dan Kim, 2011). Phycocyanin berwarna biru, phycoerythrin menghasilkan warna ungu dan phycoerythrocyanin berwarna orange. Kadar phycobiliproteins dalam rumput laut merah berkisar antara 8 - 32,7 \% (berat kering) (Sekar dan Chandramohan, 2008). Hasil penelitian menyebutkan phycobiliproteins menunjukkan aktivitas biologis yang beragam, seperti antioxidant, anti-inflammatory, neuroprotective, hypocholesterolemic, hepatoprotective, antiviral, anti-tumour, liverprotecting, atherosclerosis treatment, serum lipid-reducing dan lipase inhibition activities (Sekar dan Chandramohan, 2008).

\subsection{Bioaktif polisakarida}

Polisakarida merupakan komponen utama dari rumput laut (40-65\% dari total massa) (Meillisa et al. 2015). Polisakarida pada rumput laut tersusun dari hidrokoloid penyusun dinding se dan bahan pengisi ruang antara sel (Santi et al., 2012). Secara lebih rinci bioaktif polisakarida sulfat yang terdapat pada rumput laut dan aktivitas biologis disajikan pada Tabel 4 .

Tabel 4

Bioaktif polisakarida sulfat dan aktivitas biologis yang terdapat pada rumput laut.

\begin{tabular}{|c|c|c|c|}
\hline $\begin{array}{c}\text { Golongan } \\
\text { rumput laut }\end{array}$ & $\begin{array}{c}\text { Komponen } \\
\text { bioaktif }\end{array}$ & Sumber & Aktivitas \\
\hline \multirow[t]{8}{*}{$\begin{array}{l}\text { Rumput laut } \\
\text { coklat }\end{array}$} & Fucan & $\begin{array}{l}\text { Adenocystis } \\
\text { utricularis }\end{array}$ & Antiviral activity \\
\hline & B-glucan & $\begin{array}{l}\text { Thamnolia } \\
\text { vermicularis }\end{array}$ & $\begin{array}{c}\text { Aktivitas } \\
\text { imunomodulator }\end{array}$ \\
\hline & $\begin{array}{c}\text { Galactofuranman } \\
\text { nans }\end{array}$ & $\begin{array}{l}\text { Thamnolia } \\
\text { vermicularis }\end{array}$ & $\begin{array}{c}\text { Aktivitas } \\
\text { imunomodulator }\end{array}$ \\
\hline & Fucoidan & Ecklonia cava & $\begin{array}{l}\text { Aktivitas anti- } \\
\text { inflammatory }\end{array}$ \\
\hline & Alginat & $\begin{array}{l}\text { Saccharina } \\
\text { latissima }\end{array}$ & Antibakteri \\
\hline & & $\begin{array}{l}\text { Undaria } \\
\text { pinnatifida }\end{array}$ & Anticancer \\
\hline & Laminaran & $\begin{array}{l}\text { Saccharina } \\
\text { latissima }\end{array}$ & Antiviral \\
\hline & & $\begin{array}{l}\text { Laminaria } \\
\text { hyperborea }\end{array}$ & Hypocolesteromic \\
\hline \multirow[t]{3}{*}{$\begin{array}{l}\text { Rumput Laut } \\
\text { Merah }\end{array}$} & Porphyran & $\begin{array}{l}\text { Porphyra } \\
\text { haitanensis }\end{array}$ & $\begin{array}{l}\text { Antioksidan, } \\
\text { antikoagulan }\end{array}$ \\
\hline & Carrageenan & Chondrus crispus & Antikoagulan \\
\hline & & $\begin{array}{c}\text { Eucheuma } \\
\text { cottonii }\end{array}$ & Hypocolesteromic \\
\hline \multirow[t]{2}{*}{$\begin{array}{c}\text { Rumput Laut } \\
\text { Hijau }\end{array}$} & Rhamnam sulfat & $\begin{array}{l}\text { Monostrama } \\
\text { latissimum }\end{array}$ & Antikoagulan \\
\hline & Ulvan & $\begin{array}{l}\text { Ulva lactuta } \\
\text { Monostroma sp }\end{array}$ & $\begin{array}{c}\text { Anti tumor } \\
\text { Anti influenza. }\end{array}$ \\
\hline
\end{tabular}

Sumber : Liu et al. (2015); Holdt dan Kraan ( 2011)

Polisakarida utama yang telah diteliti mempunyai aktivitas biologis (bersifat bioaktif) dalam rumput laut adalah polisakarisa sulfat. Polisakarida sulfat yang terdapat pada rumput laut coklat diantaranya adalah laminaran, alginate, dan fucan, 
dalam rumput laut merah sering ditemui polisakarida sulfat jenis sulfated galactans seperti agar dan carrageenan (Costa et al. 2010). Sedangkan bioaktif polisakarida sulfat yang terdapat pada alga hijau adalah ulvans (Wijesekara et al., 2011).

Selanjutnya Barahona et al. (2014) menuliskan bahwa polisakarida sulfat yang terdiri dari laminaran, fucoidan dan sulfated galactan yang diekstrak dari rumput laut jenis Desmarestia distans, Lessoniavadosa, dan Gigartina skottsbergii mempunyai aktivitas antioksidan, antikoagulan dan aktivitas imunostimulan secara in vitro. Senyawa bioaktif fucoidan yang diekstrak dari rumput laut coklat mempunyai aktivitas biologis sebagai antikoagulan, antivirus, antiinflamasi, anti alergi, anti kanker dan antioksidan (Vo dan Kim, 2013). Fucoidan yang diekstrak dari rumput laut coklat Sargassum mcclurei, Sargassumpolycystum dan Turbinara ornate dari perairan Vietnam menunjukkan aktivitas anti virus HIV (Thui et al., 2015).

\subsection{Komponen serat rumput laut}

Serat merupakan komponen penting dalam bahan pangan, terutama dalam menjaga kesehatan dan keseimbangan fungsi sistem pencernaan. Serat pangan, dikenal juga sebagai serat diet atau dietary fiber, merupakan bagian dari tumbuhan yang dapat dikonsumsi dan tersusun dari karbohidrat yang memiliki sifat resistan terhadap proses pencernaan dan penyerapan di usus halus manusia serta mengalami fermentasi sebagian atau keseluruhan di usus besar. Jadi serat pangan merupakan bagian dari bahan pangan yang tidak dapat dihirolisis oleh enzim-enzim pencernaan (Santoso, 2011). Perkembangan penelitian membuktikan bahwa meski bukan zat gizi, serat pangan mempunyai fungsi yang sangat penting dalam memicu terjadinya kondisi fisiologis dan metabolik yang dapat memberikan perlindungan pada kesehatan saluran pencernaan, khususnya usus halus dan kolon (Kusharto, 2006).

Beberapa studi menunjukkan bahwa rumput laut merupakan bahan yang potensial sebagai sumber serat pangan dengan beberapa keunggulan dibandingkan dengan bahan pangan asal tumbuhan darat (Dwiyitno, 2011). Rumput laut merupakan tumbuhan laut yang telah diteliti mengandung komponen serat yang tinggi. Kandungan serat pada rumput laut bervariasi yaitu $36-60 \%$ berat kering, dimana $55-70 \%$ merupakan serat terlarut yang terdiri dari alginat dan carrageenan dengan jumlah yang bervariasi tergantung dari jenis rumput laut dan kondisi lingkungan (Tabel 5). Selanjutnya fucoidans, laminarin, porphyran, dan ulvan juga merupakan serat terlarut yang banyak terdapat pada beberapa jenis rumput laut (Rajapakse dan Kim, 2011). Astawan et al. (2006) mengemukakan bahwa rumput laut jenis Eucheuma cottonii dari perairan Indonesia mengandung kadar serat terlarut sebesar $23,89 \%$ dan serat pangan tidak larut air sebesar $55,05 \%$.

Tabel 5

Beberapa jenis serat terlarut pada rumput laut.

\begin{tabular}{ll}
\hline \multicolumn{1}{c}{$\begin{array}{c}\text { Serat terlarut } \\
\text { (hidrokoloid) }\end{array}$} & \multicolumn{1}{c}{ Sumber } \\
\hline Agar & $\begin{array}{l}\text { Rumput laut merah (gracilaria, gelidium, } \\
\text { pterocladia) } \\
\text { Rumput laut merah (eucheuma, chondrus, } \\
\text { hypnea, gigartina) } \\
\text { Rumput laut coklat (macrocystis, laminaria, } \\
\text { ascophyllum). } \\
\text { Rumput laut coklat (laminaria religiosa, } \\
\text { Alginat }\end{array} \quad \begin{array}{l}\text { Remacystus decipiens) } \\
\text { Rumput laut coklat (laminaria japonica, } \\
\text { saccharina latissima) } \\
\text { Rumput laut merah (porphyra spp) } \\
\text { Rumput laut hijau ((ulva lactuca, enteromorpha } \\
\text { Laminarin }\end{array}$ \\
Porphyran &
\end{tabular}

Manfaat serat rumput laut bagi kesehatan berkaitan dengan sifat fisiko-kimianya, terutama daya serap air, viskositas, fermentabilitas, dan kapasitas penukar ionnya. (Dwiyitno, 2011). Serat terlarut rumput laut ini mempunyai kemampuan mengikat air yang besar disebabkan sifat hidrokoloid yang dimilikinya, sehingga konsumsi rumput laut dalam diet harian akan dapat mengikat air dari makanan dan mempersingkat keberadaan makanan di kolon sehingga dapat mengurangi resiko kanker kolon (Brownlee et al. 2005).

Berbagai penelitian telah membuktian manfaat serat pangan dari rumput laut terhadap kesehatan. Harden et al. (2012) melaporkan konsumsi minuman yang diperkaya dengan alginat dari rumput laut dapat mengontrol nilai Glikemix indeks dari pasien penderita diabetes tipe 2 . Serat dari rumput laut juga dapat membantu mengontrol berat badan karena merupakan diet yang rendah kalori (Rajapakse dan Kim 2011) dan juga dapat menghambat aktivitas enzim $\alpha$-amylase dan $\alpha$-glucosidase yang berperan dalam proses penumpukan kalori di tubuh (Nwosua et al. 2011). Selanjutnya Herpandi (2005) melaporkan bahwa kadar serat pangan yang terkandung dalam tepung rumput laut Eucheuma cottonii, Gelidium sp dan Sargassum sp dari perairan Indonesia mempunyai efek hipokolesterolemik (menurunkan kolesterol) pada tikus percobaan. Semakin tinggi kadar serat pangan terutama serat pangan larut maka akan semakin baik efek fisiologis terhadap penurunan kadar kolesterol.

\subsection{Senyawa halogen}

Senyawa halogen pada rumput laut merupakan senyawa metabolit sekunder, biasanya mengandung ion halogen berupa ion clorida atau bromida dalam struktur kimianya (Cabrita et al., 2010). Secara umum ada dua golongan yaitu senyawa halogen non volatil dan senyawa halogen volatile (Gupta dan Ghannan, 2011). Senyawa halogen juga sering digolongkan sebagai monoterpena atau diterpena dan sesqueterpen (Cabrita et al., 2010).

Bioaktivitas senyawa halogen pada rumput laut juga mulai diteliti dalam beberapa tahun terakhir. Senyawa halogen dari golongan terpenoid yaitu fallachromenoic acid yang diisolasi dari rumput laut coklat Sargassum fallax di perairan Australia menunjukkan aktivitas antikanker (uji in vitro pada sel leukeumia) (Cabrita et al., 2010). Senyawa halogen bromophenols dari ekstraksi rumput Polysiphonia morrowii menunjukkan aktivitas antiviral. Demikian juga diterpen yang diekstrak dari rumput laut Dictyota pfaffii dan Dictyota menstrualisdapat menghambat infeksi virus herpes tipe I secara in vitro (Michalak dan Chojnacka, 2015). Dua jenis diterpen yaitu 4,18-dihydroxydictyolactone dan 8,11 dihydroxypachydictyol yang diisolasi dari Dictyota menunjukkan aktivitas anti tumor sel carcinoma secara in vitro (Gupta dan Ghannam, 2011).

\subsection{Potensi pemanfaatan rumput laut sebagai produk pangan fungsional}

Produksi rumput laut yang sangat besar di Indonesia akan memberikan potensi dari segi ekonomi dan kesehatan jika dilakukan pengelolaan dengan baik. Realisasi pemanfaatan rumput laut, baik yang dipanen liar maupun budidaya masih jauh dari potensi rumput laut yang ada, dan masih jauh berada dibawah negara-negara tetangga yang kondisi dan potensi rumput lautnya lebih kecil dari Indonesia. Terutama pemanfaatan sebagai poduk olahan pangan bagi masyarakat. Padahal jika ditinjau dari kandungan komponen bioaktif, rumput laut sangat berpotensi untuk dikembangkan sebagai produk 
pangan fungsional yang dapat meningkatkan kesehatan masyarakat.

Suatu produk pangan dikatakan berfungsi sebagai pangan fungsional jika dikonsumsi akan memberikan manfaat lebih bagi kesehatan selain kandungan gizi yang dimilikinya (Zakaria 2015). Rumput laut telah diteliti mengandung sejumlah komponen bioaktif yang berfungsi untuk meningkatkan kesehatan, baik sebagai antioksidan, antimikroba, anti obesitas, anti kanker, anti inflamasi dan manfaat kesehatan lainnya. Rumput laut dapat menjadi suatu produk pangan fungsional, jika dilakukan pengolahan yang tepat sehingga menghasilkan produk pangan dengan sensori yang dapat diterima, akan tetapi teknologi pengolahan yang diberikan tidak merusak komponen bioaktif yang terkandung dalam rumput laut tersebut. Ini menjadi tantangan tersendiri khususnya bagi pelaku pangan dalam menghasilkan produk pangan fungsional bagi masyarakat.

Ketersediaan produk olahan rumput laut di Indonesia masih sangat terbatas, apalagi ketersediaan produk pangan fungsional. Pengolahan rumput laut menjadi produk makanan atau minuman masih terbatas dilakukan oleh industri rumah tangga. Selain itu rendahnya kualitas rumput laut Indonesia disebabkan oleh belum adanya standar khusus yang diterapkan di tingkat petani, mulai dari proses penanaman sampai penanganan pasca panen sehingga menyebabkan rendahnya kualitas bahan baku rumput laut yang dihasilkan yang nantinya akan mempengaruhi kandungan komponen bioaktif dan proses pengolahan.

Oleh sebab itu untuk mengembangkan produk pangan fungsional berbahan baku rumput laut, beberapa hal yang harus diperhatikan adalah:

1. Perlu adanya penerapan standar penanaman dan penanganan pasca panen yang baik di tingkat petani rumput laut

2. Bahan baku rumput laut yang digunakan bebas dari cemaran logam berat dan bahan pencemar lainnya

3. Bahan baku rumput laut harus mengandung komponen bioaktif dan zat gizi yang tinggi

4. Proses pengolahan pangan yang diterapkan tidak merusak komponen bioaktif yang terkandung dalam rumput laut

Beberapa alternatif produk pangan yang dapat dikembangkan dari rumput laut Indonesia adalah: produk nori, produk minuman, manisan rumput laut, mie, cake rumput laut, kerupuk, atau juga sayuran rumput laut. Produk-produk pangan ini dapat menggunakan rumput laut sebagai bahan baku utama, sehingga nantinya akan menghasilkan produk pangan selain rasanya yang enak juga mengandung komponen bioaktif yang berkhasiat bagi kesehatan.

\section{Kesimpulan}

Pemanfaatan rumput laut sebagai produk pangan fungsional akan meningkatkan nilai tambah dari rumput laut Indonesia. Disamping itu adanya pengembangan produk pangan fungsional berbasis rumput laut akan dapat memberikan akses yang luas bagi masyarakat untuk penyediaan pangan sehat (pangan fungsional) dengan harga terjangkau.

\section{Bibliografi}

Anggadiredja, J.T., Zatnika, A., Purwoto, H., Istini, S., 2006. Rumput Laut. Jakarta (ID): Penebar Swadaya.

Astawan, M., Koswara, S., Herdiani, F., 2004. Pemanfaatan rumput laut (Eucheuma cottonii) untuk meningkatkan kadar iodium dan serat pangan pada selai dan dodol. $J$ Teknol dan Indust Pangan. 15(1) : 61-69.

Astorga-Espana, M.S., Galdon, B.R., Rodriguez, E.M., Romero, C.D., 2015. Mineral and trace element concentrations in seaweeds from the sub-Antarctic ecoregion of Magallanes (Chile). J of Food Comp and Analy. 39: 69-76. doi:org/ 10.1016/j.jfca.2014.11.010.

Barahona, T., Encinas, M.V., Imarai, M., Mansilla, A., Matsuhiro, B, Torres, R., Valenzuela, B., 2014. Bioactive polysaccharides from marine algae. J. Bioact Carbohydr and Diettary Fibre. 4: 125 - 138. doi:org/10.1016/ j.bcdf. 2014.09.002.

Bocanegra, A., Bastida, S., Benedi, J., Rodenas, S., Sanchez-Muniz F.J., 2009. Characteristics and nutritional and cardiovascular-health properties of seaweeds. J Med Food. 12 (2) : 236-258. doi:10.1089/jmf.2008.0151.

Brownlee, I.A., Allen, A., Pearson, J.P., Dettmar, P.W., Havler, M.E., Atherton, M.R., Onsoyen, E., 2005. Alginate as a source of dietary fiber. Crit. Rev. Food Sci Nutr. 45: 497510. doi : 10.1080/10408390500285673.

Cabrita, M.T., Vale, C., Rauter, A.M., 2010. Halogenated compounds from marine algae. Marine Drugs. 8: 23012317. doi:10.3390/md.8082301.

Costa, L.S., Fidelis, G.P., Cordeiro, S.L., Oliveira, R.M., Sabry, D.A., Camara, R.B.G., Nobre, L.T., Costa, M.S.S.P., AlmeidaLima, J., Farias, E.H.C., 2010. Biological activities of sulfated polysaccharides from tropical seaweeds. $J$ Biomed. Pharm. 1: 21-28.

Dwiyitno, 2011. Rumput laut sebagai sumber serat pangan potensial. Squalen. 6(1) : 9-17.

Farvin, K.H.S., Jacobsen, C., 2013. Phenolic compounds and antioxidant activities of selected species of seaweeds from Danish coast. J Food Chem. 138: 1670-1680. doi.org/10.1016/j.foodchem.2012.10.078

Firdaus, M., 2011. Phlorotanin. Malang (ID): UB. Press.

Gupta, S., Ghannam, N.A., 2011. Bioactive potential and possible health effects of edible brown seaweeds. Trends in Food Sci and Technol. 20: 1-12. doi:10.1016/j. tifs.2011.03.011.

Harden, J.C., Richardson, J.C., Dettmar, P.W., Corfe, B.M., Paxmana, J.R., 2012. An ionic-gelling alginate drink attenuates postprandial glycaemia in males. J Funct Foods. 4 : 122-128.

Herpandi, 2005. Aktivitas hipokolesterolemik tepung rumput laut pada tikus hiperkolesterolemia. [Tesis]. Bogor. (ID): Institut Pertanian Bogor.

Holdt, S.L., Kraan, S., 2011. Bioactive compounds in seaweed: Functional food applications and legislation. J Applied Phycol. 23: 543-597. Doi: 10.1007/ s10811-010-9632-5.

Jeyabalan, J.P.P., Marimuthu, J., 2012. Preliminary phytochemical analysis of Sargassum myriocystum and 
Turbinaria ornata from the Southern Coast of Tamil Nadu, India. J Tropical Biomed Asian Pacific. 4 : 1-4.

Kemenkes, R.I, 2014. Situasi dan Analisis Diabetes. Pusat Data dan Informasi Kemetrian Kesehatan. Jakarta (ID). Kementrian Kesehatan RI.

Keyrouz, R., Abasq, M.L., Bourvellec, C.L., Blanc, N., Audibert, L., Argall, E., Hauchard, D., 2011. Total phenolic contents, radical scavenging and cyclic voltammetry of seaweeds from Brittany. Food Chem. 126: 831-836. doi: 10.1016/j.foodchem.2010.10.061.

Kim, S.K., Pangestuti, R., 2011. Biological activities and potential health benefits of fucoxanthin derived from marine brown algae. Advans in Food and Nutri Res. 64: 111-128. doi: 10.1016/B978-0-12-387669-0.00009-0.

Kusharto, C.M., 2006. Serat makanan dan peranannya bagi kesehatan. J Gizi dan Pangan. 1(2) : 45-54.

Liu, J., Willfor, S., Xu, C., 2015. A review of bioactive plant polysaccharides: Biological activities, functionalization, and biomedical applications. Bioactv Carbohydr and Diettary Fibre. 5: 31 -61. doi: org/10.1016/ j.bcdf. 2014. 12.001 .

Loupatty, V.D., 2014. Nori nutrient analysis from seawed of porphyra marcossi in Maluku ocean. Eksakta. 14(2); 3448.

Mabeau, S., Fleurence, J., 1993. Seaweed in food products: biochemical and nutritional aspects. Trends Food Sci Technol. 4: 103-107.

Machado, D.I.S., Cervantes, J.L., Hernandez J.L., Losada, P.P., 2004. Fatty acids, total lipid, protein and ash contents of processed edible seaweeds. J Food Chem. 85: 439-444. doi: 10.1016/j.foodchem.2003.08.001.

Machu, L., Misurcova, L., Ambrozova, J.V., Orsavova, J., Mlcek, J., Sochor, J., Jurikova, T., 2015. Phenolic content and antioxidant capacity in alga food products. Molecules. 20: 1118-1133. doi:10.3390/molecules20011118.

Meillisa, A., Woo, H.C., Chun, B.S., 2015. Production of monosaccharides and bio-active compounds derived from marine polysaccharides using subcritical water hydrolysis. J Food Chem. 171: 70-77. doi.org/10.1016/ j. foodchem. 2014.08.097.

Michalak, I., Chojnacka, K., 2015. Algae as production systems of bioactive compounds. Eng Life Sci. 15: 160-176. doi: 10.1002/elsc.201400191.

Nisizawa, K., Noda, H., Kikuchi, R., Watanabe, T., 1987. The main seaweed foods in Japan. Hydrobiology. 19 :5-29.

Nwosua, F., Morrisa, J., Lunda, V.A., Heather, D.S., Rossa, A., McDougall, G.J., 2011. Anti-proliferative and potential anti-diabetic effects of phenolic-rich extracts from edible marine algae. J Food Chem. 126(3): 1006-1012. doi:10.1016/ j. foodchem.2010.11.111.

Okai, Y., Hiqashi, O., Yano, Y., Otani, S., 1996. Identification of antimutagenic substances in an extract of edible red alga
Porphyra tenera (Asadusa-nori). Cancer Letters. 100: 235-240.

Ortiz, J., Bozzo, C., Navarrete, E., Osorio, A., Rios, A., 2006. Dietary fiber, amino acid, fatty acid and tocopherol contents of the edible seaweeds Ulva lactuca and Durvillaea antarctica. J Food Chem. 99: 98-104. doi:10.1016/ j. foodchem.2005.07.027.

Pangestuti, R., Kim, S.K., 2011. Biological activities and health benefit effects of natural pigments derived from marine algae. J Functl Foods. 3: 255-266. doi: 10.1016/j.jff.2011.07.001

Rajapakse, N., Kim, S.K., 2011. Nutritional and digestive health benefits of seaweed. Adv in Food and Nutr Res. 64: 17 28. doi: 10.1016/B978-0-12-387669-0.00002-8.

Santi R.A., Sunarti, T.C., Santoso, D., Triwisari, D.A., 2012. Komposisi kimia dan profil polisakarida rumput laut hijau. J Akuatika. 3 (2) : 105-114.

Santoso, A., 2011. Serat pangan (dietary fiber) dan manfaatnya bagi kesehatan. Magistra. 75 (23): 35-40.

Sekar, S., Chandramohan, M., 2008. Phycobiliproteins as a commodity: trends in applied research, patents and commercialization. J Appl Phycol. 20:113-136. doi 10.1007/s10811-007-9188-1.

Thuy, T.T.T., Ly, B.M., Van, T.T.T., Quang, N.V., Tu, H.C., Zheng, Y., Devaux, C.S., Mi, B., Ai, U., 2015. Anti-HIV activity of fucoidans from three brown seaweed species. J Carbohdr Polymers. 115: 122-128. doi:org/10.1016/ j.carbpol. 2014.08.068

Vo, T.S., Kim, S.K., 2013. Fucoidans as a natural bioactive ingredient for functional foods. J of Funct Foods. 5: 16 27. doi:org/10.1016/j.jff.2012.08.007.

Wijesekara, I., Pangestuti, R., Kim, S.K., 2011. Biological activities and potential health benefits of sulfated polysaccharides derived from marine algae. J Carbohydr Polymers. 84(1): 14-21. doi: 10.1016/j.carbpol.2010.10.062.

Yoshie, Y., Suzuki, T., Shirai, T., Hirano, T., 1994. Changes in the contents of dietary fibres, minerals, free amino acids, and fatty acids during processing of dry Nori. Nippon Suisan Gakk. 60: 117-123.

Yunizal, 2004. Teknik Pengolahan Alginat. Jakarta: Pusat Riset Pengolahan Produk dan Sosial Ekonomi Kelautan dan Perikanan.

Zakaria, F.R., 2015. Pangan Nabati, Utuh dan Fungsional sebagai Penyusun Diet Sehat. Bogor. (ID). Orasi IImiah Guru Besar Institut Pertanian Bogor 